\title{
HUBUNGAN STATUS SOSIAL DAN PERISTIWA TUTUR ANTARA APARAT DESA DAN MASYARAKAT
}

\author{
Safitri Djafar \\ Kantor Bahasa Gorontalo \\ Jalan Dokter Zainal Umar Sidiki, Tunggulo, Tilongkabila, Bone Bolango \\ Pos-el:safitridjafar@gmail.com
}

\begin{abstract}
Abstrak
Penelitian ini bertujuan mendeskripsikan status sosial, peristiwa tutur, serta hubungan status sosial dan peristiwa tutur antara aparat desa dan masyarakat di Kantor Desa Lonuo Kecamatan Tilongkabila Kabupaten Bone Bolango, dilihat dari tingkat ekonomi, pendidikan, dan pekerjaan. Metode yang digunakan yaitu metode kualitatif dengan jenis penelitian deskriptif. Data dalam penelitian ini yakni ujaran oleh aparat desa dan masyarakat Desa Lonuo. Sumber data diperoleh dari aparat desa dan masyarakat Desa Lonuo Kecamatan Tilongkabila Kabupaten Bone Bolango. Hasil penelitian menunjukkan (1) status sosial masyarakat Desa Lonuo dilihat dari tingkat ekonomi berada di bawah rata-rata dan pendidikan masyarakat pada umumnya sampai pada tingkat pendidikan sekolah dasar, (2) peristiwa tutur terjadi antara pihak kecamatan, aparat desa dan masyarakat dalam kegiatan rapat koordinasi kelompok tani serta antara masyarakat dan kepala dusun II dalam kegiatan pembuatan surat keterangan tidak mampu, dan (3) hubungan status sosial dan peristiwa tutur sangat erat, serta peristiwa tutur ini menunjukkan adanya perbedaan penggunaan bahasa dilihat dari status sosial pada tingkat pendidikan setiap penutur.
\end{abstract}

Kata Kunci: hubungan, sosial, peristiwa tutur, aparat desa, masyarakat

\section{The Relation of The Social Status and Speech Events Between Society and Village Officers}

\begin{abstract}
The purpose of this research is to describe the social status, speech events, and relation between the social status and the speech events between village officers and the society in Kantor Desa Lonuo, KecamatanTilongkabila, KabupatenBone Bolango, viewed from the economic, educational, and employment levels. The method used is the qualitative method and the type of research is descriptive research. The data in this study were the utterances spoken by village officers and the society in DesaLonuo. The data sources were obtained from the village officers and the society in Lonuo. The results showed: (1) the social status of the society in Lonuo was seen from the economic level, it was below the average and the public education only reached the level of primary school (2) speech events occur between the sub-district officers, the village officers, and the society in a meeting activities, or in meeting coordination of farmer groups, and between the society and kepala dusun II in the making of a poverty statement, and (3) the relation between social status and speech events is very close, and this speech event shows differences in the use of language that had been seen from social status at the level of education of each speaker.
\end{abstract}

Keywords: relation, social, speech events, village officer, community

\section{PENDAHULUAN}

Sosialisasi dalam masyarakat berlangsung secara intertekstual, lintas peristiwa (Wortham, 2005). Dalam sosialisasi tersebut, terlibat berbagai kalangan masyarakat dari berbagai status sosial. Dalam kaitannya dengan bahasa, status sosial tersebut bahkan dapat memicu 
pergesaran leksikon dalam keluarga (Sodah, 2019).

Status sosial merupakan kedudukan yang melekat pada diri seseorang didalam masyarakat. Menurut Spencer (dalam Sugihen, (Bahrein T, 1997), status seseorang atau sekelompok orang dapatditentukan oleh suatu indeks. Indeks seperti ini dapat diperoleh dari jumlah ratarata skor, misalnya yang dicapai seseorangdalam masing-masing bidang seperti pendidikan, pendapatan tahunan keluarga, dan pekerjaan dari kepala rumah tangga (breadwinner).Jadi, status sosial seseorang di dalam masyarakat dapat diperoleh secara sengaja misalnya status sosial berdasarkan tingkat ekonomi, pendidikan, dan pekerjaanserta status sosial yang diperoleh secara pasti misalnya status soial berdasarkan jenis kelamin dan usia.

Status sosial seseorang memengaruhi cara mengungkapkan pendapat. Hal ini berdasarkan fakta di lapangan bahwa semakin tinggi tingkat pendidikan seseorang, akan semakin bagus pula caranya dalam mengungkapkan pendapat atau berbicara. Namun,hal ini tidak bisa dijadikan patokan, karena adapula orang yang semakin tinggi tingkat pendidikannya, akan tetapi caranya mengungkapkan pendapat tidak bisa dijadikan teladan.

Pengungkapan pendapat seseorang terjadi dalam interaksi antara dia dan orang lain. Interaksi dengan adanya pertukaran informasi antara satu orang dengan orang lain ini disebut peristiwa tutur. Menurut Aslinda dan Leni(Aslinda dan Syafyahya, 2007) peristiwa tutur merupakan interaksi linguistik untuk saling menyampaikan informasi antara dua belah pihak tentang suatu topik atau pokok pikiran, waktu, dan tempat.

Peristiwa tutur yang terjadi dalam masyarakat berbeda-beda. Perbedaan ini terjadi karena status sosial setiap orang berbeda. Peneliti menemukan perbedaan status sosial di salah satu kantor desa, yakni di kKantor Desa Lonuo Kecamatan Tilongkabila Kabupaten Bone Bolango.
Perbedaan status sosial ini terlihat antara aparat desa dan masyarakat.

Status sosial yang berbeda antara aparat desa dan masyarakat yakni status sosial berdasarkan tingkat ekonomi, pendidikan, dan pekerjaan. Adanya perbedaan status sosial ini, menimbulkan pula perbedaan peristiwa tutur antara aparat desa dan masyarakat. Sehingga peneliti merasa tertarik untuk meneliti peristiwa tutur antara aparat desa dan masyarakat. Serta hubungan status sosial dan peristiwa tutur antara aparat desa dan masyarakat di Kantor Desa Lonuo Kecamatan Tilongkabila Kabupaten Bone Bolango.

Penelitian ini mengkaji hubungan status sosial dan peristiwa tutur yang terjadi dalam masyarakat. Namun, hubungan yang dikaji dalam penelitin ini berfokus pada aparat Desa LonuoKecamatan Tilongkabila Kabupaten Bone Bolango dan masyarakatnya.

Hubungan status sosial dan peristiwa tutur ini dikaji oleh peneliti karenaadanya perbedaan yang terjadi dalam peristiwa tutur berdasarkan status sosial seseorang dalam masyarakat. Misalnya peristiwa tutur yang terjadi antara aparat desa dan petani penggunaan bahasanya lebih sederhana. Namun, peristiwa tutur antara aparat desa dan guru akan lebih menggunakan bahasa yang mengandung istilah ilmiah.

Hubungan status sosial dengan peristiwa tutur antara aparat desa dan masyarakat ini dikaji, untuk melihat bagaimana hubungan antara status sosial yang melekat pada diri seseorang dalam masyarakat dengan peristiwa tutur yang terjadi antara dirinya dengan orang lain. Tentunya setiap perbedaan status sosial akan menciptakan peristiwa tutur yang berbeda pula.

Penelitian mengenai hubungan status sosial dan peristiwa tutur telah banyak dilakukan, tetapi tetap menarik untuk terus dilakukan mengingat tujuannya melibatkan banyak faktor sosial dan latar belakang budaya. Keragaman bahasa bahkan dapat terlihat dari pekerjaan seseorang. Kita juga sekaligus dapat mengetahui bagaimana 
komunikasi muncul di antara peserta tutur dan mengekplorasi perbedaan dan persamaan dalam interaksi yang terjadi dalam bahasa dan budaya yang berbeda. Penelitian Al-Ghamdi dan Alrefaee mengonfirmasi hal tersebut (Al-Ghamdi \& Alrefaee, 2020). Studi tersebut bertujuan untuk menyelidiki strategi penolakan penutur bahasa Arab Yaman dan penutur bahasa Inggris Amerika untuk menjelaskan kemungkinan area perbedaan dan persamaan lintas budaya. Penelitian itu berfokus pada peran status sosial lawan bicara dalam menghasilkan penolakan. Hasil penelitian menunjukkan bahwa perbedaan lintas budaya terbukti. Orang Yaman cenderung lebih langsung daripada orang Amerika, terutama dengan interaksi status sosial yang lebih rendah dan setara. Ada perbedaan yang substansial dalam frekuensi beberapa strategi penolakan. Perbedaan lintas budaya juga terlihat dengan penggunaan beberapa strategi oleh satu kelompok saja. Salah satu perbedaan lintas budaya yang mencolok adalah dalam penggunaan khusus untuk menyebut nama Tuhan yang lebih sering disambung oleh orang Yaman. Penelitian ini juga membuktikan bahwa status sosial sangat memengaruhi penggunaan dan pemilihan strategi penolakan di antara orang Yaman dan Amerika. Misalnya, Yaman menggunakan strategi alternatif hanya ketika menolak tawaran dengan status yang lebih tinggi, sementara strategi ini digunakan di semua interaksi oleh orang Amerika. Dalam status yang setara, orang Yaman menggunakan strategi langsung sementara orang Amerika ditemukan menggunakan alasan dan strategi tambahan rasa syukur. (Al-Ghamdi \& Alrefaee, 2020).

Penelitian Fatma, dkk juga mengonfirmasi bahwa penggunaan bahasa dalam suatu komunikasidipengaruhi oleh budaya peserta tutur. Bahasa yang digunakan dalam komunikasi lisan mencerminkan sistem kepercayaan dan norma yang berkembang dalam masyarakat tertentu. Perbedaan dialek yang diperoleh masyarakat menyebabkan perbedaan cara penggunaan bahasa sebagai media komunikasi, termasuk bahasa daerah, untuk menyampaikan tujuan dan makna secara komunikatif kepada peserta. Ada bentuk khusus yang digunakan oleh penutur dan pendengar yang memiliki dua dialek berbeda. Penelitian itu menggunakan etnografi komunikasi yang melibatkan aspek tuturan untuk menguraikan berbagai faktor yang mempengaruhi pilihan bahasa. Hal ini secara sederhana mengungkapkan dalam temuan penelitian tersebut bahwa pilihan bahasa digunakan (1) untuk menjelaskan makna tertentu yang tidak memiliki padanan translasi dalam Bahasa Indonesia, (2) untuk menciptakan suasana yang lebih akrab di antara para lulusan, (3) untuk meniadakan atau meminimalkan pengajar dan pembatasan kekuasaan, (4) untuk menyampaikan implikasi tertentu dari suatu tindak tutur, (5) untuk menunjukkan tingkat penolakan dan / atau penerimaan terhadap sesuatu dan untuk menunjukkan simpati atau empati dengan menggunakan vokatif tertentu, (6) dan untuk menciptakan suasana kelas yang kondusif . Selanjutnya faktor-faktor pilihan bahasa daerah yang digunakan dalam konteks wacana akademik perguruan tinggi dipengaruhi oleh budaya peserta tutur, latar belakang akademik, keakraban, status sosial, lingkungan keluarga, usia, dan jenis kelamin.(Fatma et al., 2018).

Selain itu, ada penelitian yang dilakukan oleh Haji, A. Haris Tahun 2016 dengan judul skripsi Tindak Tutur Berbahasa Gorontalo Masyarakat Desa Pelambane Kecamatan Randangan. Adapun fokus penelitiannya yakni bagaimanakah tindak tutur berbahasa Gorontalo masyarakat Desa Pelambane Kecamatan Randangan dilihat dari fungsi pertuturan.(Haji, 2016)

Berdasarkan hasil penelitian yang dilakukan Haji tersebut, relevansinya dengan penelitian ini yakni mengkaji tuturan oleh masyarakat. Namun, perbedaanya penelitian ini mengkaji peristiwa tutur oleh masyarakat dan aparat 
desa, sementara penelitian Haris A. Haji mengkaji tindak tutur oleh masyarakat itu sendiri. Perbedaan peristiwa tutur dan tindak tutur yakni, peristiwa tutur merupakan rangkaian dari sejumlah tindak tutur, sedangkan tindak tutur merupakan proses penuturan oleh satu individu saja.

Pengkajian masalah dalam penelitian ini, telah dilakukan berdasarkan pengumpulan dan penganalisisandata di lapangan. Berdasarkan permasalahan yang telah dikemukakan di atas, peneliti merumuskan judul penelitian ini yakni "Hubungan Status Sosial dan Peristiwa Tutur Antara Aparat Desa dan Masyarakat di Kantor Desa LonuoKecamatan TilongkabilaKabupaten Bone Bolango".

\section{TEORI}

\section{Pengertian Status Sosial}

Status sosial merupakan jabatan sosial yang berlaku dalam masyarakat. Status merupakan kedudukan seseorang yang dapat ditinjau terlepas dari individunya. Sementara itu menurut Spencer (dalam Sugihen,(Bahrein T, 1997) status seseorang atau sekelompok orang dapat ditentukan oleh suatu indeks. Indeks seperti ini dapat diperoleh dari jumlah rata-rata skor, misalnya yang dicapai seseorang dalam masing-masing bidang seperti pendidikan, pendapatan tahunan keluarga, dan pekerjaan dari kepala rumah tangga (breadwinner).

Lebih lanjut dipaparkan

bahwaKedudukan (status) seringkali dibedakan dengan kedudukan sosial (social status). Kedudukan adalah sebagai tempat atau posisi seseorang dalam suatu kelompok sosial, sehubungan dengan orang lain dalam kelompok tersebut, atau tempat suatu kelompok sehubungan dengan kelompok-kelompok lain di dalam kelompok yang lebih besar lagi. Selanjutnya kedudukan sosial adalah tempat seseorang secara umum dalam masyarakat sehubungan dengan orang lain, dalam arti kewajibannya. Kedudukan sosial tidaklah semata-mata merupakan kumpulan kedudukan-kedudukan seseorang dalam kelompok yang berbeda, tapi kedudukan sosial tersebut mempengaruhi kedudukan orang tadi dalam kelompok sosial yang berbeda. Namun, untuk mendapatkan pengertian yang mudah kedua istilah tersebut akan digunakan dalam pengertian yang sama, yaitu kedudukan (status).

Pendapat beberapa ahli tersebut melahirkan suatu pengertian baru bahwa status sosial merupakan kedudukan obyektif yang memberi hak dan kewajiban kepada orang yang menempati kedudukan tadi. Pengertian status sosial menurut peneliti tersebut mengacu pada pengertian status sosial menurut Spencer, sebagaimana telah dipaparkan sebelumnya yang menjadi tolok ukur dalam penelitian ini. Beberapa pendapat para ahli tersebut, menuntun peneliti untuk lebih condong pada pendapat Spencer mengenai status sosial. Penelitian ini mengacu pada status sosial berdasarkan pendidikan, ekonomi, dan pekerjaan. Selanjutnya beberapa pendapat para ahli mengemukakan bahwa perbedaan status sosial mempengaruhi bahasa yang mereka gunakan. Menurut Sumarsono (Sumarsono, 2017) perbedaan atau penggolongan kelompok masyarakat manusia bisa tercermin dalam ragam bahasa golongan masyarakat itu. Ia juga berpendapat bahwa perbedaan bahasa dapat menimbulkan perbedaan gaya kognisi (atau gaya belajar). Hal ini sejajar dengan hipotesis oleh Edward Sapir dan Benjamin Lee Whorf (Muhammad, 2011)bahwa cara berpikir dan bertindak anggota masyarakat penutur dipengaruhi oleh bahasa.

Status sosial didefinisikan sebagai suatu strata(lapisan) orang-orang yang berkedudukan sama dalam kontinu (rangkaian kesatuan) status sosial. Definisi ini memberitahukan bahwa dalam masyarakat terdapat orang-orang yang secara sendiri-sendiri atau bersama-sama memiliki kedudukan sosial yang kurang lebih sama. Mereka yang memiliki kedudukan kurang lebih sama akan berada pada suatu lapisan yang kurang lebih sama pula. 
Safitri Djafar: Hubungan Status Sosial dan Peristiwa Tutur antara Aparat Desa dan Masyarakat

Status sosial adalah tingkatan yang ada dalam masyarakat. Masyarakat mempunyai beberapa tingkatan, dalam masyarakat Bali tingakatan sosial ini masih berlaku. Namun, seiring perkembangan zaman tingkatan sosial dalam masyarakat Bali tidak lagi ditentukan oleh garis keturunan, tetapi ditentukan oleh tingkat pendidikan masyarakat itu.

Tingkatan sosial dalam masyarakat dapat dilihat dari beberapa segi. Ada empat komponen ciri-ciri status sosial, yaitu pekerjaan, sumber pendapatan, tipe rumah, dan kawasan tempat tinggal. Salah satu imbalan dari status yang tinggi adalah adanya pengakuan sebagai orang yang berderajat tinggi, karena orang kaya dan bangsawan tampak seperti orang lain, maka mereka memerlukan berbagai cara agar kedudukan mereka bisa diakui. Pada masa lalu caranya ialah dengan menggunakan simbol status, yang bisa berwujud suatu tindak-tanduk terpuji atau barang yang sangat langka, seperti mobil, jas berbulu binatang, dan intan. Nilai status barang tersebut dihargai sebagaimana halnya dengan nilai kegunaan dan keindahannya. Jadi, status sosial seseorang ada yang melekat sejak lahir misalnya usia dan jenis kelamin, serta ada pula status sosial yang diperoleh secara sengaja misalnya pendidikan dan tingkat ekonomi.

\section{Pengertian Peristiwa Tutur}

Peristiwa tutur adalah terjadinya interaksi yang melibatkan dua pihak, yaitu penutur dan mitra tutur dengan satu pokok tuturan dalam waktu, tempat, situasi tertentu. Chaer dan Agustina (Chaer, Abdul dan Agustina, 2004)berpendapat bahwa peristiwa tutur adalah berlangsungnya atau terjadinya interaksi linguistik dalam satu bentuk ujaran atau lebih yang melibatkan dua pihak, yakni penutur dan mitra tutur dengan satu pokok tuturan dalam waktu, tempat, dan situasi tertentu.

Pendapat lain juga dikemukakan oleh Aslinda dan Syafyahya, 2007bahwa peristiwa tutur adalah terjadinya interaksi linguistik untuk saling menyampaikan informasi antar dua belah pihak tentang satu topik atau pokok pikiran, waktu, tempat, dan situasi tertentu. Pandangan keempat ahli di atas telah menerangkan peristiwa tutur adalah interaksi dalam waktu, tempat, dan situasi tertentu.

Menurut Dell Hymes ((Aslinda dan Syafyahya, 2007), terdapat delapan unsur yang harus diperhatikan dalam penggunaan bahasa, yakni Setting and Scene, Participant, Ends, Act Sequences, key, Instrumentalities, Norms of Interaction and Interpretation dan Genre. Jadi, dapat disimpulkan bahwa peristiwa tutur terjadi secara bersamaan dengan waktu, tempat, dan situasi tertentu. Berdasarkan beberapa pendapat para ahli tersebut, peneliti dalam penelitian ini lebih condong pada teori yang diungkapkan Hymes mengenai penggunaan bahasa dalam suatu peristiwa tutur.

Berdasarkan pengertian peristiwa tutur tersebut, secara konkret kita dapat menentukan interaksi yang disebut sebagai peristiwa tutur linguistik, antara lain rapat di kantor, diskusi dalam ruangan perkuliahan, sidang di pengadilan, serta interaksi antara pedagang dan pembeli di pasar atau warung. Namun, pembicaraan yang terjadi di dalam bus kota atau di dalam kereta api yang terjadi di antara penumpang yang tidak saling mengenal, dengan topik pembicaraan yang tidak menentu, tanpa tujuan, dengan ragam bahasa yang berganti-ganti, tidak dapat dikatakan sebagai peristiwa tutur secara sosiolinguistik. Hal ini karena pokok pembicaraannya tidak menentu (bergantiganti), tanpa tujuan dan dilakukan oleh orang yang tidak sengaja berbicara.

\section{Komponen Tutur}

Peristiwa tutur yang terjadi karena didukung oleh beberapa komponen. Komponen-komponen yang mendukung terjadinya peristiwa tutur disebut Komponen Tutur. Menurut seorang ahli Sosiolinguistik terkenal Hymes (Aslinda dan Syafyahya, 2007)peristiwa tutur harus memenuhi delapan komponen tutur yang diakronimkan menjadi SPEAKING. Kedelapan komponen tersebut adalah Setting and Scene, Participant, Ends, Act 
Sequences, Key, Instrumentalities, Norms of Interaction and Interpretation dan Genre. Peneliti menggunakan komponen tutur menurut Hymes, karena semua komponennya bisa menjabarkan peristiwa tutur yang terjadi. Di bawah ini penjelasan mengenai delapan komponen tutur yang wajib dipenuhi oleh penutur dan mitra tutur dalam peristiwa tutur.

a. Setting and Scene (Waktu, Tempat, dan Situasi)

Setting berhubungan dengan waktu dan tempat pertuturan berlangsung sementara Scene mengacu pada situasi, tempat, dan waktu terjadinya pertuturan, waktu, tempat, dan situasi yang berbeda dapat menyebabkan penggunaan variasi bahasa berbeda. Misalnya percakapan yang dilakukan di lapangan sepak bola ketika ada pertandingan dengan situasi yang ramai, tentu akan berbeda dengan percakapan yang dilakukan di perpustakaan pada waktu banyak orang yang sedang membaca.

\section{b. Participants (Peserta Tutur)}

Participantsadalah peserta tutur atau pihakpihak yang terlibat dalam pertuturan, yakni adanya penutur dan ada mitra tutur. Status sosial penutur menentukan ragam bahasa yang digunakan, misalnya seorang jaksa dalam persidangan akan berbeda ragam bahasa yang digunakan ketika berbicara dengan anak-anaknya di rumah.

c. Ends (Maksud dan Tujuan)

Ends mengacu pada maksud dan tujuan tuturan. Di dalam ruang seminar misalnya penyaji berusaha menjelaskan maksud yang dibuatnya, sementara pendengar (peserta) sebagai mitra tutur berusaha mempertanyakan maksud yang disajikan penutur.

d. Act Sequences (Bentuk dan Isi Ujaran)

Act Sequences berkenaan dengan bentuk ujaran dan isi ujaran. Bentuk berkaitan dengan kata-kata yang digunakan sementara isi berkaitan dengan topik pembicaraan.

e. Key (Nada Suara)

Key berhubungan dengan nada suara, penjiwaan, sikap atau cara saat sebuah tuturan diujarkan, misalnya dengan gembira, santai dan serius.

\section{f. Instrumentalities (Saluran dan Bentuk Bahasa)}

Instrumentalities berkenaan dengan saluran dan bentuk bahasa yang digunakan dalam pertuturan. Saluran misalnya oral, tulisan, isyarat, baik berhadap-hadapan maupun melalui telepon untuk yang saluran oral, tulisan bisa juga dalam telegram.

g. Norms of Interaction and Interpretation (Norma atau Aturan)

Norms of Interaction and Interpretation, norma-norma atau aturan yang harus dipahami dalam interaksi. Norma interaksi dicerminkan oleh tingkat oral atau hubungan sosial dalam sebuah masyarakat bahasa.

h. Genres (Bentuk Penyampaian)

Menurut Chaer dan Agustina (Chaer, Abdul dan Agustina, 2004), genre mengacu pada bentuk penyampaian, seperti puisi, pepatah, doa, dan sebagainya.

\section{METODE}

Metode danpendekatan yang digunakan dalam penelitian ini adalah kualitatif. Penelitian kualitatif dipilih dalam penelitian ini, karena peneliti menganalisis hubungan status sosial dengan peristiwa tutur antara aparat desa dan masyarakat. Peneliti mengobservasi langsung peristiwa tutur yang terjadi di Kantor Desa Lonuo Kecamatan Tilongkabila Kabupaten Bone Bolango. Selanjutnya mencatat dan merekam peristiwa tutur tersebut. Kemudian menganalisis hubungan status sosial dengan peristiwa tutur antara aparat desa dan masyarakat yang melakukan komunikasi di kKantor Desa Lonuo Kecamatan Tilongkabila Kabupaten Bone Bolango.

Jenis penelitian ini adalah deskriptif. Penelitian ini mendeskripsikan hubungan status sosial dan peristiwa tutur yang terjadi antara aparat desa dan masyarakat di kKantor Desa Lonuo Kecamatan Tilongkabila Kabupaten Bone Bolango.Status sosial dan peristiwa tutur diamati secara langsung oleh peneliti di kKantor Desa Lonuo Kecamatan Tilongkabila Kabupaten Bone Bolango. 
Penelitian ini dilakukan di Kantor Desa Lonuo Kecamatan Tilongkabila Kabupaten Bone Bolango. Lokasi kantor desa digunakan oleh peneliti, karena di kantor desa tersebut banyak peristiwa tutur yang terjadi baik secara formal misalnya rapat, dan non formal misalnya pengurusan surat menyurat oleh masyarakat. Hal ini menarik bagi peneliti untuk mengkaji peristiwa tutur tersebut, karena masyarakat yang berada di desa tersebut memiliki status sosial yang berbeda, utamanya jika dilihat dari segi pendidikan dan pekerjaan. Sebagian besar masyarakat di desa tersebut adalah petani.

\section{HASIL PENELITIAN DAN PEMBAHASAN}

Masyarakat desa Lonuo terbagi dalam tiga dusun. Jumlah keseluruhan masyarakat Desa Lonuo ada 831 jiwa. Masyarakat dusun I, terdapat 368 jiwa. Dusun II terdapat 289 jiwa, dan dusun III terdapat 174 jiwa. Data jumlah penduduk ini berdasarkan pendataan penduduk bulan April 2018.

Data status sosial masyarakat Desa Lonuo, terbagi dalam tiga bagian, berdasarkan status sosial ekonomi, pendidikan, dan pekerjaan. Status sosial ekonomi terbagi dalam tiga tingkatan.
Tingkat ekonomi keluarga prasejahtera terdapat 95 keluarga, keluarga sejahtera I terdapat 100 keluarga, keluarga sejahtera II terdapat 29 keluarga, keluarga sejahtera III terdapat 20 keluarga, dan keluarga sejahtera III plus terdapat 10 keluarga.

Data status sosial berdasarkan tingkat pendidikan terbagi dalam tingkat pendidikan TK terdapat 40 jiwa, pendidikan SD terdapat 95 jiwa, pendidikan SMP terdapat 52 jiwa, pendidikan SMA terdapat 34 jiwa, pendidikan kuliah terdapat 15 jiwa, tamat SD terdapat 290 jiwa, tamat SMP terdapat 47 jiwa, tamat SMA terdapat 101 jiwa, pendidikan DIII terdapat 6 jiwa, pendidikan sarjana terdapat 23 jiwa, dan magister terdapat 2 jiwa. Data status sosial berdasarkan pekerjaan yakni PNS terdapat 25 jiwa, Swasta terdapat 41 jiwa, petani terdapat 103 jiwa, dan buruh tani terdapat 68 jiwa.

\section{PEMBAHASAN}

a. Status Sosial Berdasarkan Tingkat Ekonomi Masyarakat DesaLonuo Data status sosial berdasarkan tingkat ekonomi setiap keluarga adalah sebagai berikut:

b.

Tabel 1

Tingkat Ekonomi Masyarakat DesaLonuo

\begin{tabular}{|c|c|c|c|c|}
\hline Ekonomi & Dusun I & Dusun II & Dusun III & Jumlah \\
\hline Prasejahtera & 35 & 31 & 29 & 95 \\
\hline KS I & 53 & 34 & 13 & 100 \\
\hline KS II & 16 & 9 & 4 & 29 \\
\hline KS III & 8 & 5 & 7 & 20 \\
\hline KS III+ & 7 & 3 & - & 10 \\
\hline
\end{tabular}

Keterangan:

Prasejahtera: Keluarga yang belum dapat memenuhi kebutuhan dasarnya (basic need) secara minimal, seperti kebutuhan akan spiritual, pangan, sandang, papan, kesehatan dan KB.

KSI: Keluarga Sejahtera I, yaitu keluarga yang dapat memenuhi 
kebutuhan dasarnya secara minimal, tetapi belum dapat memenuhi kebutuhan sosial psikologisnya seperti kebutuhan akan pendidikan, KB, dan transportasi.

KS II: Keluarga Sejahtera II, yaitu keluarga disamping telah memenuhi kebutuhan dasarnya, juga telah dapat memenuhi kebutuhan pengembangannya seperti kebutuhan untuk menabung dan memperoleh informasi.

KS III: Keluarga Sejahtera III, yaitu keluarga yang telah dapat memenuhi seluruh kebutuhan dasar, kebutuhan sosial, psikologis, dan perkembangan keluarganya, tetapi belum dapa tmemberikan sumbangan yang teratur bagi masyarakat, khususnya banyak tumbunhnya pohon aren di area gunung.

\section{c. Status Sosial Berdasarkan Tingkat Pendidikan Masyarakat Desa Lonuo}

Tabel 2

Tingkat Pendidikan Masyarakat DesaLonuo

\begin{tabular}{|c|c|c|c|c|}
\hline Pendidikan & Dusun I & Dusun II & Dusun III & Jumlah \\
\hline TK Paud & 14 & 21 & 5 & 40 \\
\hline SD & 45 & 36 & 14 & 95 \\
\hline SMP & 20 & 21 & 11 & 52 \\
\hline SMA & 17 & 12 & 5 & 34 \\
\hline KULIAH & 4 & 7 & 4 & 15 \\
\hline Tamat SD & 148 & 88 & 54 & 47 \\
\hline Tamat SMP & 23 & 17 & 7 & 101 \\
\hline Tamat SMA & 40 & 35 & 26 & 6 \\
\hline D III & 1 & 3 & 2 & 23 \\
\hline SARJANA & 12 & 7 & 4 & 2 \\
\hline
\end{tabular}

Berdasarkan data tingkat pendidikan masyarakat Desa Lonuo, terlihat bahwa sebagian besar masyarakat Desa Lonuo mempunyai pendidikan hanya sampai pada tingkat sekolah dasar. Masyarakat Desa Lonuo yang tamat sekolah Dasar berjumlah 290 orang.
Selanjutnya tingkat pendidikan masyarakat Desa Lonuo, sampai pada tingkat sekolah menengah atas. Berdasarkan data, terdapat 101 masyarakat desa Lonuo yang sudah lulus SMA.

\section{d. Status Sosial Berdasarkan Tingkat Pekerjaan Masyarakat DesaLonuo}

Tabel 3

Tingkat Pekerjaan Masyarakat DesaLonuo

\begin{tabular}{|c|c|c|c|c|}
\hline Pekerjaan & $\begin{array}{c}\text { Dusun } \\
\text { I }\end{array}$ & $\begin{array}{c}\text { Dusun } \\
\text { II }\end{array}$ & Dusun III & Jumlah \\
\hline PNS & 14 & 9 & 6 & 25 \\
\hline Swasta & 18 & 17 & 32 & 41 \\
\hline Petani & 20 & 51 & 10 & 68 \\
\hline Buruh Tani & 51 & 7 & & 103 \\
\hline
\end{tabular}


Berdasarkan tingkat pekerjaan masyarakat Desa Lonuo sebagian besar berprofesi sebagai petani. Hal ini di dukung oleh lahan di desa ini masih cukup luas untuk dijadikan tempat pemerolehan sumber daya alam. Sehingga sebagian besar masyarakat di desa ini memilih bertani sebagai pekerjaan utama.

Sesuai hasil data tingkat ekonomi, tingkat pendidikan, dan tingkat pekerjaan masyarakat Desa Lonuo, sebagian besar masyarakat Desa Lonuo mempunyai ekonomi berdasarkan di bawah rata-rata pendapatan ekonomi. Selanjutnya berdasarkan tingkat pendidikan masyarakat Desa Lonuo sudahmempunyai pendidikan. Meskipun sebagian besar pendidikan masyarakat Desa Lonuo hanya sampai pada tingkat sekolah dasar. Namun, sesuai data tersebut sebagian besar masyarakat sudah bisa membaca, menulis, dan berhitung.

Data tingkat ekonomi dan tingkat pendidikan masyarakat Desa Lonuo ini, menggambarkan bahwa status sosial masyarakat Desa Lonuo sudah berada pada rata-rata. Status sosial ini jika dilihat dari tingkat ekonomi, masyarakat Desa Lonuo sudah bisa memenuhi kebutuhan hidupnya setiap hari. Meskipun pendapatan mereka tidak menentu. Akan tetapi, seluruh masyarakat Desa Lonuo tidak ada yang kelaparan dalam satu hari.

Selanjutnya jika dilihat dari tingkat pendidikan, masyarakat Desa Lonuo sudah bisa mengenyam pendidikan secara keseluruhan. Tingkat pendidikan masyarakat Desa Lonuo lebih banyak hanya sampai pada taraf pendidikan dasar. Tetapi hal tersebut tidak membatasi masyarakat Desa Lonuo untuk melakukan komunikasi menggunakan Bahasa Indonesia yang baik dan benar.

\section{e. Peristiwa Tutur antara Aparat Desa dan Masyarakat di Kantor Desa Lonuo dalam Rapat Koordinasi Kelompok Tani}

P 1: "Hadirin yang kami hormati. Kami dari pemerintah desa akan membagikan bibit kepada para petani berdasarkan sistem Basis Data Terpadu (BDT). Sistem ini sesuai aturan dari Pemerintah Dinas Sosial". ("Hadirin yang kami hormati. Kami dari pemerintah desa akan membagikan bibit kepadapara petani, berdasarkan sistem Basis Data Terpadu (BDT). Sistem ini berdasarkan aturan dari Pemerintah Dinas Sosial")

P 2: "Bapak-bapak dan ibu-ibu, kami dari pemerintah Kecamatan Tilongkabila sudah mendengar keluhan dari masyarakat Desa Lonuo mengenai pembagian bibit yang tidak mendapat persetujuan dari pihak pemerintah desa. Olehnya kami dari pemerintah kecamatan sekali lagi menekankan bahwa pembagian bantuan kepada masyarakat harusnya berdasarkan sistem Basis Data Terpadu (BDT)." ("Bapak-bapak dan ibu-ibu, kami dari pemerintah Kecamatan Tilongkabila sudah mendengar keluhan dari masyarakat Desa Lonuo mengenai pembagian bibit yang tidak mendapat persetujuan dari pihak pemerintah desa. Olehnya kami dari pemerintah kecamatan sekali lagi menekankan bahwa pembagian bantuan kepada masyarakat harusnya berdasarkan sistem Basis Data Terpadu (BDT).")

P 3: "Kami dari pihak masyarakat dan kelompok tani tidak mempermasalahkan mengenai pembagian bantuan, yang memang seharusnya berdasarkan sistem Basis Data Terpadu (BDT). Kami hanya mempertanyakan mengenai pembagian bibit kepada petani, karena yang kami tahu pembagian bibit ini berdasarkan acuan dari Dinas Pertanian. Dimana dinas pertanian mengembangkan aturan pemerintah untuk kedaulatan 
pangan, yang untuk pembagian bibit berdasarkan Calon Petani Calon Lahan (CPCL)". ("Kami dari pihak masyarakat dan kelompok tani tidak mempermasalahkan mengenai pembagian bantuan, yang memang seharusnya berdasarkan system Basis Data Terpadu (BDT). Kami hanya mempertanyakan mengenai pembagian bibit kepada petani, karena yang kami tahu pembagian bibit ini berdasarkan acuan dari Dinas Pertanian. Dimana dinas pertanian mengembangkan aturan pemerintah untuk kedaulatan pangan, yang untuk pembagian bibit berdasarkan Calon Petani Calon Lahan (CPCL)")

P 4: "Terima kasih atas kesempatan yang telah diberikan kepada saya, berdasarkan masalah pembagian bibit tadi. Saya ingin bertanya mengapa tidak dihadirkan saja antara kedua pemerintah ini, yakni Pemerintah Dinas Sosial dan Dinas Pertanian, guna membahas mengenai Basis Data Terpadu (BDT) dan Calon Petani Calon Lahan (CPCL)". ("Terima kasih atas kesempatan yang telah diberikan kepada saya, berdasarkan masalah pembagian bibit tadi. Saya ingin bertanya mengapa tidak dihadirkan saja antara kedua pemerintah ini, yakni Pemerintah Dinas Sosial dan Dinas Pertanian, guna membahas mengenai Basis Data Terpadu (BDT) dan Calon Petani Calon Lahan(CPCL)")

P 1: "Bapak-bapak dan ibu-ibu, sebelumnya saya sudah berupaya untuk menghadirkan pihak Dinas Sosial, dengan menelepon pihak Dinas Sosial. Namun, pihak Dinas Sosial yang seharusnya hadir masih melaksanakan tugas di luar daerah. Untuk pihak Dinas Pertanian, sekarang sudah diwakilkan oleh penyuluh pertanian." ("Bapak-bapak dan ibu-ibu, sebelumnya saya sudah berupaya untuk menghadirkan pihak Dinas Sosial, dengan menelepon pihak Dinas Sosial. Namun, pihak Dinas Sosial yang seharusnya hadir masih melaksanakan tugas di luar daerah.
Untuk pihak Dinas Pertanian, sekarang sudah diwakilkan oleh penyuluh pertanian.")

P 2: "Sedikit tambahan dari saya, untuk memperjelas mengenai pembagian bibit ini. Bagaimana jika kelompok tani mendatangi pihak Dinas Pertanian di kantor, yang tentunya didampingi oleh pemerintah Desa". ("Sedikit tambahan dari saya, untuk memperjelas mengenai pembagian bibit ini. Bagaimana jika kelompok tani mendatangi pihak Dinas Pertanian di kantor, yang tentunya didampingi oleh pemerintahDesa".)

P 5: "Saya selaku pemerintah desa menyarankan, untuk selanjutnya kita dari pihak desa mengagendakan kembali rapat mengenai pembagian bibit yang menghadirkan pemerintah dinas sosial dan dinas pertanian. Agar kesalahapahaman mengenai pembagian bibit ini akan terselesaikan dengan baik. Sehingga tidak terjadi kesalahpahaman antara masyarakat dan pemerintah desa". ("Saya selaku pemerintah desa menyarankan, untuk selanjutnya kita dari pihak desa mengagendakan kembali rapat mengenai pembagian bibit yang menghadirkan pemerintah dinas sosial dan dinas pertanian. Agar kesalahapahaman mengenai pembagian bibit ini akan terselesaikan dengan baik. Sehingga tidak terjadi kesalahpahaman antara masyarakat dan pemerintah desa")

Keterangan:

P 1 : Kepala Desa Lonuo

P 2 : Pihak Kecamatan Tilongkabila

P 3 : Masyarakat Desa Lonuo/Ketua

Kelompok TaniP 4 : Masyarakat Desa

Lonuo

P 5 : Kepala Dusun II

Berikut analisis proses tuturan berdasarkan delapan komponen tutur peristiwa tutur:

1. Setting and Scene (Waktu, Tempat, danSituasi)

Sesuai hasil rekaman peneliti waktu 
terjadinya percakapan di atas yaitu pada sore hari, saat dimulainya Rapat Koordinasi Kelompok Tani di Kantor Desa Lonuo. Tempat terjadinya proses tuturan ini di Aula Kantor Desa Lonuo. Sementara situasi dalam percakapan ini terjadi pada situasi yang ramai.

1. Participants (Peserta Tutur)

Peserta tutur yang terlibat yaitu pihak kecamatan, kepala desa, kepala dusun II, dan masyarakat. Kepala desa bertindak sebagai penutur dan kepala dusun dan masyarakat sebagai mitra tutur.

2. Ends (Maksud dan Tujuan)

Maksud dan tujuan terjadinya pertuturan yaitu membahas mengenai sistem pembagian bibit jagung.

3. Act Sequences (Bentuk dan Isi Ujaran)

Isi ujaran dalam yaitu untuk mendapatkan solusi mengenai pembagian bibit jagung, apakah sesuai sistem Basis Data Terpadu (BDT) atau berdasarkan Calon Petani Calon Lahan (CPCL).

\section{Key (Nada Suara)}

Nada suara yang ada dalam percakapan tersebut, baik antara penutur (kepala desa) dan mitra tutur mempunyai nada suara yang tenang dan tetap terdengar sopan.

5. Instrumentalities (Saluran dan Bentuk

Bahasa)

Saluran dan bentuk bahasa yang ada dalam percakapan tersebut, yaitu saluran bahasa lisan. Saluran bahasa lisan digunakan dalam percakapan ini, karena percakapan antara penutur (kepala desa) dan mitra tutur (kepala dusun 2 dan masyarakat) terjadi secara langsung tanpa perantara.

\section{Norms of Interaction and}

Interpretation (Norma atau Aturan)

Sesuai hasil rekaman proses tuturan di atas, maka antara penutur (kepala desa) dan mitra tutur (kepala dusun 2 dan masyarakat) tetap mematuhi norma yang berlaku. Dalam percakapan tersebut tidak terjadi tindak kekerasan atau sesuatu yang menyalahi norma.
Penutur (kepala desa) dan mitra tutur (kepala dusun 2 dan masyarakat) mematuhi norma dalam pelaksanaan interaksi dan interpretasi percakapantersebut.

7. Genres (Bentuk Penyampaian)

Bentuk penyampaian dalam percakapan tersebut, secara keseluruhan menggunakan bahasa baku. Penggunaan bahasa baku antara penutur (kepala desa) dan mitra (kepala dusun 2 dan masyarakat) terjadi karena percakapan tersebut antara seorang pimpinan dan bawahannya. Percakapan ini terjadi dengan penggunaan bahasa baku secara langsung.

Data mengenai proses tuturan tersebut menjelaskan bahwa masyarakat Desa Lonuo dalam kegiatan formal yakni rapat dapat menggunakan Bahasa Indonesia yang baik dan benar. Baik aparat desa maupun masyarakat mampu mengungkapkan pendapat ataupun tujuan tuturan kepada lawan tutur.

Penggunaan bahasa pada peristiwa tutur antara aparat desa dan masyarakat dalam rapat koordinasi kelompok tani, terlihat dalam tabel berikut: 


\begin{tabular}{|c|l|l|}
\hline Penutur & Yang dituturkan & $\begin{array}{c}\text { Penggunaan } \\
\text { Bahasa } \\
\text { Indonesia }\end{array}$ \\
\hline & $\begin{array}{l}\text { "Hadirin yang } \\
\text { kami hormati. }\end{array}$ & \\
P 1: & $\begin{array}{l}\text { Kami dari } \\
\text { pemerintah desa }\end{array}$ & Baku \\
Kepala & akan & \\
Desa & membagikan & \\
Lonuo & bibit kepada & \\
& para petani & \\
& berdasarkan & \\
& sistem Basis & \\
& Data Terpadu & \\
(BDT). & \\
& "Kami dari & \\
& pihak & \\
P 3: & masyarakat dan & \\
Masyarak & kelompok tani & \\
at / Ketua & tidak & Baku \\
Kelompo & kan mengenai & \\
k Tani & pembagian & \\
& bantuan, yang & \\
& memang & \\
& seharusnya & \\
& berdasarkan & \\
& sistem Basis & \\
& Data Terpadu & \\
& BDT). & \\
&
\end{tabular}

Berdasarkan tabel penggunaan bahasa tersebut, terlihat bahwa penggunaan Bahasa Indonesia dalam peristiwa tutur menggunakan Bahasa Indonesia baku. Kepala desa dan masyarakat menggunakan Bahasa Indonesia yang baku. Sehingga proses interaksi dalam rapat tersebut terlaksana dengan baik, serta permasalahan yang didiskusikan dalam rapat mendapat solusi dan kesepakatan pada akhir rapattersebut.

Penggunaan bahasa dalam peristiwa tutur ini dipengaruhi oleh status sosial penutur. Hal ini terlihat pada penutur tiga, berdasarkan data hasil wawancarabahwa penutur tiga tersebut merupakan masyarakat sekaligus ketua kelompok tani, mempunyai tingkat ekonomi KS III+ (Keluarga Sejahtera Tiga Plus). Keluarga Sejahtera Tiga Plus yaitu keluarga yang telah dapat memenuhi seluruh kebutuhan dasar, kebutuhan sosial, psikologis, dan perkembangan keluarganya, serta dapat memberikan sumbangan secara teratur dan sukarela untuk kegiatan sosial masyarakat dalam bentuk materi. Aktif sebagai pengurus yayasan dan instansi.

Selanjutnya berdasarkan dari tingkat pendidikan penutur tiga mempunyai pendidikan yakni DIII Ilmu Kepemerintahan. Tingkat pendidikan penutur tersebut mempengaruhi penguasaan Bahasa Indonesia, sehingga penggunaan Bahasa Indonesia penutur menjadi baik. Sementara, berdasarkan tingkat pekerjaan penutur tiga berprofesi sebagai pengusaha pembibitan ayam. Pekerjaan penutur tiga ini, menuntutnya untuk menggunakan Bahasa Indonesia yang baik dan benar. Sehingga membantu beliau dalam berkomunikasi dengan mitrausahanya.

\section{f. Peristiwa Tutur Antara Aparat Desa dan Masyarakat dalam Pengurusan Surat Keterangan TidakMampu}

P 1: “Assalamu'alaikum. Bolo maapu. Saya Cuma mo minta surat keterangan tidak mampu" (Assalamu'allaikum, maaf saya ingin meminta surat keterangan tidak mampu)

P 2 : “Untuk apa?" (Untuk apa)

P 1 : "Pongurusanialaa dana duka" (Untuk pengurusan dana duka)

P 2 : "Ooh iyaa tunggu sadiki" (Iya, silahkan ibu menunggu sebentar)

$$
\text { P1: "Ooh saya"(Iya) }
$$

P 2: "Botimao surat li ibu. Setelah ditandatangi oleh ayahanda, nanti ke kecamtan minta tanda tangan camat" ("Ibu, ini suratnya. Setelah ditandatangani oleh kepala desa, ibu ke kantor camat dan minta tanda tangan pak camat")

P 1 : "Makase Pak" (Terima Kasih pak) P 2 : "Iya sama sama" (Sama-sama ibu) 
Safitri Djafar: Hubungan Status Sosial dan Peristiwa Tutur antara Aparat Desa dan Masyarakat

Keterangan:

$\begin{array}{ll}\text { P1 } & \text { : Masyarakat } \\ \text { P2 } & \text { : Kepala Dusun II }\end{array}$

Berikut analisis proses tuturan berdasarkan delapan komponen tutur peristiwa tutur:

1. Setting and Scene (Waktu, Tempat, dan Situasi)

Sesuai hasil rekaman peneliti waktu terjadinya percakapan di atas yaitu pada pagi hari. Tempat terjadinya proses tuturan ini di Ruangan Kepala Dusun II. Sementara situasi dalam percakapan ini terjadi pada situasi yang ramai dan serius.

2. Participants (Peserta Tutur)

Peserta tutur yang terlibat yaitu pihak kepala dusun II dan masyarakat. Kepala dusun II bertindak sebagai penutur dan kepala dusun dan masyarakat sebagai mitra tutur.

3. Ends (Maksud dan Tujuan)

Maksud dan tujuan terjadinya pertuturan yaitu membahas mengenai pengurusan surat keterangan tidak mampu.

4. Act Sequences (Bentuk dan Isi Ujaran) Isi ujaran dalam yaitu masyarakat tersebut meminta kepada kepala dusun II untuk membuat surat keterangan tidak mampu guna pengurusan dana duka.

5. Key (Nada Suara)

Nada suara yang ada dalam percakapan tersebut, baik antara penutur (kepala desa) dan mitra tutur mempunyai nada suara yang tenang dan tetap terdengar sopan.
6. Instrumentalities (Saluran dan Bentuk Bahasa)

Saluran dan bentuk bahasa yang ada dalam percakapan tersebut, yaitu saluran bahasa lisan. Saluran bahasa lisan digunakan dalam percakapan ini, karena percakapan antara penutur (kepala dusun II) dan mitra tutur (masyarakat) terjadi secara langsung tanpa perantara.

7. Norms of Interaction and Interpretation (Norma atau Aturan) Sesuai hasil rekaman proses tuturan di atas, maka antara penutur (kepala dusun II) dan mitra tutur (masyarakat) tetap mematuhi norma yang berlaku. Dalam percakapan tersebut tidak terjadi tindak kekerasan atau sesuatu yang menyalahi norma. Penutur (kepala dusun II) dan mitra tutur (masyarakat) mematuhi norma dalam pelaksanaan interaksi dan interpretasi percakapan tersebut.

8. Genres (Bentuk Penyampaian) Bentuk penyampaian dalam percakapan tersebut, secara keseluruhan menggunakan campuran bahasa baku dan bahasa daerah. Penggunaan bahasa tersebut digunakan oleh masyarakat guna melancarkan penyampaian tujuan tuturan yang dilakukan.Penggunaan bahasa pada peristiwa tutur antara aparat desa dan masyarakat dalam pengurusan surat keterangan tidak mampu, dapat dilihat dalam tabel berikut : 
Berdasarkan proses tuturan tersebut terlihat bahwa penggunaan bahasa Indonesia dalam penyampaian maksud kebutuhan sosial psikologisnya seperti kebutuhan akan pendidikan, KB, dan transportasi. Selanjutnya berdasarkan

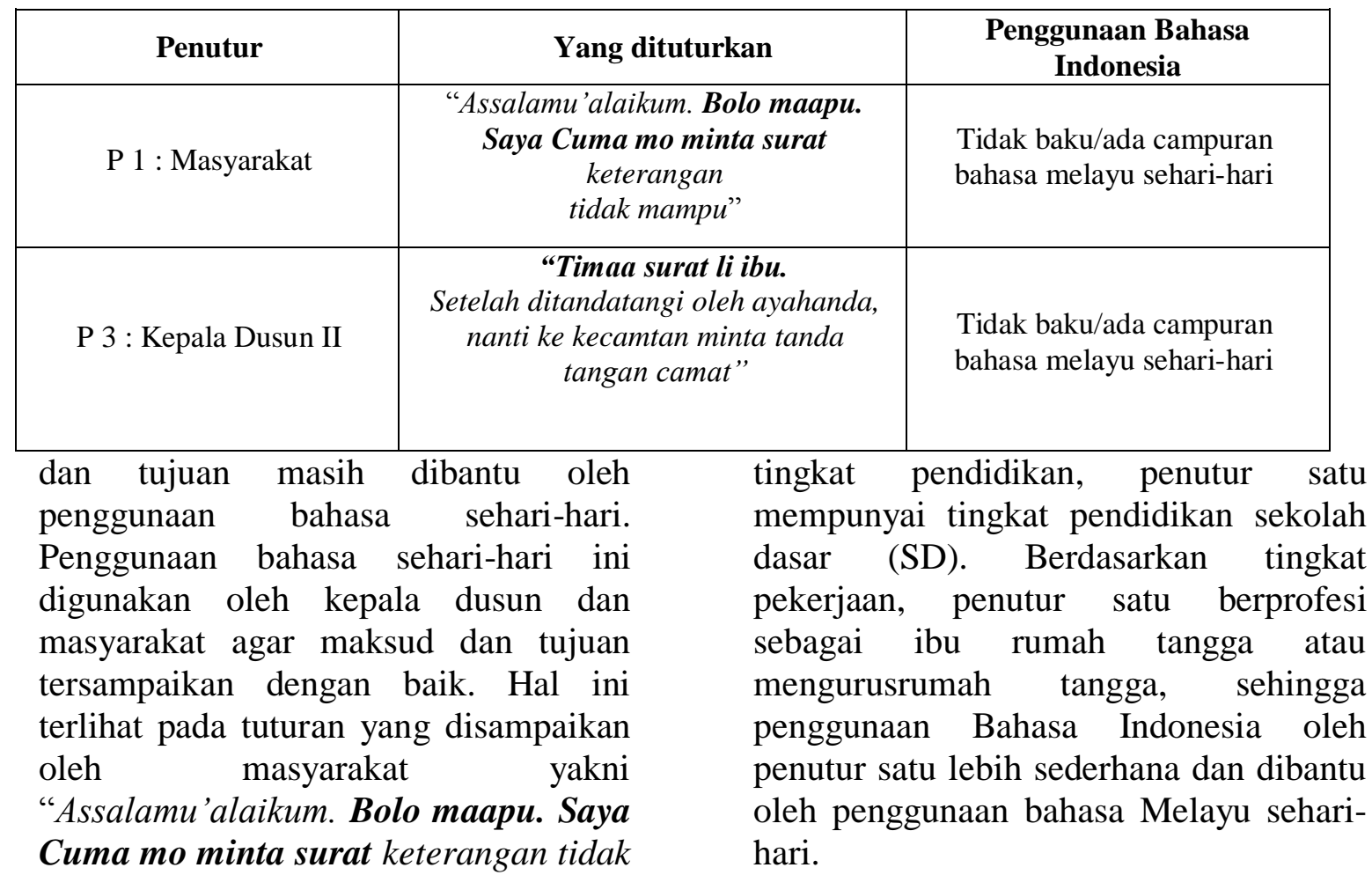
mampu". Tuturan "Bolo maa'pu. Saya Cuma mo minta surat", merupakan penggunaan bahasa melayu sehari-hari. Bolo maa'pu merupakan bahasa daerah Gorontalo yang artinya mohon maaf, sedangkan Saya Cuma mo mintasuratmerupakan bahasa MelayuManado sehari-hari. Penggunaan bahasa melayu Manado banyak digunakan oleh masyarakat Desa Lonuo, karena dulunya berdasarkan letak otonomi daerah Provinsi Gorontalo merupakan bagian dari Provinsi Sulawesi Utara yang ibukotanya Manado.

Penggunaan bahasa dalam peristiwa tutur ini dipengaruhi oleh tingkat ekonomi, pendidikan, dan pekerjaan. Berdasarkan data hasil wawancara, penutur satu yakni masyarakat yang mengurus surat keterangan tidak mampu, mempunyai tingkat KS 1

(Keluarga Sejahtera 1). Keluarga Sejahtera I, yaitu keluarga yang dapat memenuhi kebutuhan dasarnya secara minimal, tetapi belum dapat memenuhi

\section{PENUTUP}

Berdasarkan pembahasan mengenai hubungan status sosial dan peristiwa tutur antara aparat desa dan masyarakat di Kantor Desa Lonuo Kecamatan Tilongkabila Kabupaten Bone Bolango, disimpulkan bahwa hubungan status sosial dan peristiwa tutur ini sangat erat. Meskipun terjadi beberapa perbedaan antara kedua objek ini.

Dilihat dari tingkat pendidikan, masyarakat Desa Lonuo sudah bisa mengenyam pendidikan secara keseluruhan. Tingkat pendidikan masyarakat Desa Lonuo lebih banyak hanya sampai pada taraf pendidikan dasar. Tetapi hal tersebut tidak membatasi masyarakat Desa Lonuo untuk melakukan komunikasi menggunakan Bahasa Indonesia yang baik dan benar.

Hubungan bahasa dan status sosial sangat erat. Penggunaan bahasa dalam proses tuturan pada status sosial masyarakatdengan tingkat pendidikan sekolah dasar, menggunakan bahasa yang sederhana dan lugas serta dibantu oleh penggunaan bahasa sehari-hari. Sementara 
itu penggunaan bahasa pada masyarakat dengan tingkat pendidikan menengah atas dan sarjana menggunakan bahasa formal dan komunikatif.

\section{DAFTAR PUSTAKA}

Al-Ghamdi, N., \& Alrefaee, Y. (2020). The role of social status in the realization of refusal speech act: A cross-cultural study. Asian ESP Journal, 16(1-2), 207-221.

Aslinda dan Syafyahya, L. (2007). Pengantar Sosiolinguistik. Refika Aditama.

Bahrein T, S. (1997). Sosiologi Pedesaan. RajaGrafindo Persada.

Chaer, Abdul dan Agustina, L. (2004). Sosiolinguistik: Sebuah Perkenalan Awal (Vol. 284). Rineka Cipta. https://lib.unnes.ac.id/17153/1/120140 8017.pdf

Fatma, F., Sumarlam, S., \& Suwandi, S. (2018). Various Language Choice Factors on Local Language Directive Speech Acts at University in Centralof Sulawesi. September 2019. https://doi.org/10.2991/ictte18.2018 .10

Haji, H. A. (2016). Tindak Tutur Berbahasa Gorontalo Masyarakat Desa Pelambane Kecamatan Randangan.

Muhammad. (2011). Metode Penelitian Bahasa. Ar-Ruzz Media.

Sodah, N. (2019). International Journal of Multicultural and Multireligious Understanding The Impact of Social Status on Language Shift: A Case Study on Family Domain Language in Lembar. 959-967.

Sumarsono. (2017). Sosiolinguistik. Pustaka Pelajar.

Wortham, S. E. F. (2005). Socialization beyond the Speech Event. Journal of Linguistic Anthropology, 15(1), 95112.

https://doi.org/10.1525/jlin.2005.15.1. 95 
Telaga Bahasa Vol.8, No.1, April 2020 